Gut, 1978, 19, 844-850

\title{
Membrane lipid composition of red blood cells in liver disease: regression of spur cell anaemia after infusion of polyunsaturated phosphatidylcholine
}

\author{
G. SALVIOLI, G. RIOLI, R. LUGLI, AND R. SALATI \\ From the Department of Clinical Medicine, University of Modena, Modena, Italy
}

SUMMARY The morphology of red blood cells was studied in 30 patients with severe liver cirrhosis, in 10 patients with extrahepatic jaundice, and in 10 control subjects. In all the patients with extrahepatic jaundice more than $30 \%$ of red blood cells were target cells with increased resistance to osmotic lysis. In 12 patients with liver cirrhosis more than $30 \%$ of red blood cells were spur cells. The cholesterol: phospholipids (C/PL) molar ratio was 0.89 in target cells, 1.33 in spur cells, and 0.74 in normal red blood cells. The red blood cell membrane cholesterol and phospholipids exchanged with plasma lipoproteins, the lipid composition of which was studied in eight patients with spur cells; the free cholesterol: phospholipid (FC/PL) molar ratio was $0.33(0 \cdot 16$ in the controls) in high density lipoproteins (HDL) and $1.40(0.82$ in the controls) in low density lipoproteins (LDL); in these patients the polyunsaturated fatty acid content was low in both phospholipids and cholesterol esters of lipoproteins. The irregular folds of the spur cells regressed when polyunsaturated lecithin was infused ( $2 \mathrm{~g}$ daily for five days) in eight patients with spur cell anaemia; the infusions decreased both $\mathrm{C} / \mathrm{PL}$ ratio in $\mathrm{RC}$ to 0.88 and the concentration of unconjugated bilirubin (104.3 to $82.0 \mu \mathrm{mol} / 1(6.1$ to $4.8 \mathrm{mg} \%)$, whereas the activity of the plasma lecithin:cholesterol acyltransferase (LCAT) increased from 31.2 to $54.4 \mu \mathrm{mol} / \mathrm{l} / \mathrm{h}$. Polyunsaturated fatty acid content of RC lecithin increased after the infusion as it did in HDL, the FC/PL ratio of which decreased to $0 \cdot 23$.

The erythrocyte is a complex structure the shape of which depends partly on the lipid composition of its membrane (Shohet, 1972). The fluidity of the membrane is influenced by cholesterol-phospholipid interactions (Kimelberg and Papahadjapoulos, 1974); both increase of C/PL molar ratio and decrease of polyunsaturated fatty acids make the red blood cell membrane more rigid (Bruckdorfer et al., 1969). In patients with liver disease there are abnormalities of erythrocyte lipid content and accompanying changes of their morphology. An increased resistance of red blood cells to osmotic lysis is often met in patients with extrahepatic obstruction of the biliary tract and can be attributed to a characteristic increase of the surface-to-volume ratio (Cooper and Jandl, 1968); these erythrocytes appear as target cells on stained smears. Smith $e t$ al. (1964) described a syndrome occurring in patients with severe liver cirrhosis, designated as 'spur cell anaemia', because of the projections from the

Received for publication 26 January 1978 surface of red blood cells. Spur cells have a low tendency to deform and show a high content of cholesterol (Cooper et al., 1974). While the presence of target cells has no significance with respect to the disease, anaemia may occur in patients with spur cells, although their osmotic fragility is unchanged. To reduce anaemia, splenectomy is carried out because the spleen is the organ responsible for the destruction of spur cells (Cooper et al., 1974). Cooper et al. (1975) were able to normalise the in vitro $\mathrm{C} / \mathrm{PL}$ molar ratio by adding saturated phosphatidylcholine to spur cell serum; this prevented a rise in membrane cholesterol and an increase of cell surfaces as well as the transformation of normal red blood cells to spur cells. In rodents cells are depleted of cholesterol in vivo after infusion of a pure phospholipid dispersion (Robins and Miller, 1974).

As spur cells are characterised by a high C/PL molar ratio and because of their low polyunsaturated fatty acid content, it is suggested that this type of haemolytic anaemia should be treated with polyunsaturated phosphatidylcholine infusions. 


\section{Methods}

\section{PATIENTS STUDIED}

Ten patients with extrahepatic obstruction, 30 patients with advanced cirrhosis of the liver, and 10 control subjects were studied. In all cases, the diagnosis was supported by data from biochemical and histological tests and from laparotomy.

Patients were included in the study only if they had no haemoglobinopathies or deficiencies of red blood cell enzymes. Patients with spur or target cells were designated as such if they had more than $30 \%$ of these abnormal cells. Osmotic fragility of erythrocytes was estimated according to Parpart et al. (1947), using a graded sequence of concentrations of $\mathrm{NaCl}(4 \mathrm{ml})$ to which $0.1 \mathrm{ml}$ blood was added; resistance to osmotic lysis is increased when, at an $\mathrm{NaCl}$ concentration of $3.5 \mathrm{~g} / 1$, haemolysis is lower than $50 \%$.

Eight patients with spur cells were infused daily with $2 \mathrm{~g}$ polyunsaturated phosphatidylcholine (EPL, essential phospholipids supplied by Nattermann, Rome) for five days. EPL is a solution of soybean phosphatidylcholine in sodium deoxycholate (4\%); its fatty acid composition is ( $\%$ of weight) $16: 013 \%, 18: 03.6 \%, 18: 17.5 \%, 18: 2$ $66.9 \%, 18: 39 \%$.

After the infusion, osmotic fragility, morphology, lipid and fatty acid content of red blood cells, and lipid lipoprotein composition were studied. Unconjugated bilirubin, reticulocytes, and LCAT activity (Stokke and Norum, 1971) were also measured before and after infusions.

\section{RED CELL MORPHOLOGY}

Red cell morphology as well as the percentage of spur cells and target cells were assessed by Giemsa stained smears. The presence of spicular erythrocytes was verified by examination of fresh wet preparations using an inverted phase-contrast microscope (Zeiss). In each wet preparation the percentage of spur cells was determined in a differential of 300 to 400 cells.

LIPID COMPOSITION OF RED BLOOD CELLS Blood samples treated with EDTA Na2 $(2.68 \mathrm{mmol} / \mathrm{l})$ were centrifuged at $800 \mathrm{rpm} \times 10$ minutes at $+4^{\circ} \mathrm{C}$. The red blood cells were then washed three times with $\mathrm{NaCl}(150 \mathrm{mmol} / \mathrm{l})$ and EDTA $\mathrm{Na}_{2}$ $(0.01 \mathrm{mmol} / \mathrm{l})$. Two millitres of saline were added to $2 \mathrm{ml}$ of packed red blood cells, and the red blood cells were counted to allow a calculation of the lipid content per $10^{10}$ erythrocytes. One millitre of packed red blood cells was extracted with chloroform: methanol $(1: 1)$ containing $0.2 \%$ butylhydroxytoluene (BHT) to prevent lipid peroxidation. Extracts were washed with $0 \cdot 1 \mathrm{~N} \mathrm{KCl}$ to remove non- lipid phosphorus. Aliquots of the lipid extracts were used for cholesterol (Biochemia Kit No. 15949) and phospholipid determination (Bartlett, 1959). The remaining extract was used for lecithin isolation on precoated silica gel $\mathrm{G}$ plates (Merck). The methyl esters of the lecithin fatty acids were studied as for phospholipids of lipoprotein (see below).

\section{PLASMA COMPOSITION OF LIPIDS AND BILE ACIDS}

Free and total cholesterol was determined using an enzymatic method (Biochemia Kit No. 124079), triglycerides using the Biochemia kit no. 15970, and lipid phosphorus according to Bartlett (1959). Concentration and composition of serum bile acids were determined by gas-liquid chromatography (Salvioli et al., 1974).

Low density lipoproteins $(\mathrm{d}=1006-1063)$ and high density lipoproteins $(\mathrm{d}=1063-1210 \mathrm{~g} / \mathrm{ml})$ were separated by serial preparative ultracentrifugation with the aid of solid $\mathrm{KBr}$ to obtain optimal densities (Hatch and Lees, 1968). The proteins (Lowry et al., 1951), free and esterified cholesterol, triglycerides, and phospholipids content of LDL and HDL were determined. Aliquots of the two lipoproteins were extracted with chloroform: methanol $(2: 1)$ containing $0.2 \%$ butylhydroxytoluene (BHT). Phospholipids and cholesterol esters were isolated by thin layer chromatography on silica gel G plates developed with hexane:diethylether:acetic acid $(80: 20: 1)$ containing $0.4 \%$ BHT.

The fatty acid composition of phospholipids and cholesterol esters of HDL and LDL obtained by transmethylation with boronfluoride methanol (Morrison and Smith, 1964) was studied by gas-liquid chromatography using a column filled with $15 \%$ diethylene glycol succinate polyester on Chromosorb W (Appled Science Laboratories, Inc.) in a Packard Becker gas chromatograph mod. 420. The individual fatty acid methyl esters were identified by comparison with the relative retention time of standard fatty acids. The relative composition of the different fatty acids was calculated as the product of the peak height and the width at half height. The results are reported in terms of percentage of area, which corresponds to percentage of mass.

\section{Results}

\section{RED CELL MORPHOLOGY (Table 1)}

In all patients with obstructive jaundice morphology of the red blood cells revealed target cells. In patients with cirrhosis of the liver spur cells were present in 12 cases $(40 \%)$, while target cells were observed in only two patients. Osmotic fragility was reduced in all the patients with obstructive jaundice and in 
11 patients with cirrhosis of the liver (36\%); of these, four only presented changed osmotic fragility.

\section{LIPID COMPOSITION OF RED BLOOD CELLS}

The cholesterol content was increased in spur cells and, particularly, in target cells; the phospholipid content was normal in spur cells but the C/PL molar ratio was increased $(P<0.01)$ (Table 2). The C/PL ratio was increased in patients with target cells but the results were not statistically significant. The initial values of the fatty acid composition of the phosphatidylcholine in the erythrocytes showed a low content of linoleic acid (18:2) in spur cells (P < 0.01) (Table 3).

Table 2 Lipid content of red cells $(R C)$ in controls and in patients with spur cells and target cells

\begin{tabular}{lccc}
\hline Groups (no.) & $\begin{array}{l}\text { Cholesterol } \\
\left(\mathrm{mg} / 10^{10} \mathrm{RC}\right)\end{array}$ & $\begin{array}{l}\text { Phospholipids } \\
\left(\mathrm{mg} / 10^{10} \mathrm{RC}\right)\end{array}$ & $\begin{array}{l}\text { Cholesterol:phospholipids } \\
(\mathrm{mol}: \mathrm{mol})\end{array}$ \\
\hline Controls (10) & 1.12 & 3.06 & 0.74 \\
& \pm 0.27 & \pm 0.51 & \pm 0.10 \\
Spur & 1.58 & 2.97 & $1.33^{*}$ \\
cells (12) & \pm 0.18 & \pm 0.68 & \pm 0.16 \\
Target & 2.07 & $4.64 \dagger$ & 0.89 \\
cells (10) & \pm 0.58 & \pm 0.79 & \pm 0.18 \\
\hline
\end{tabular}

${ }^{*} \mathrm{P}<0.01$ between spur cells and the controls.

tP $<0.05$ between target cells and the controls.

\section{SERUM LIPIDS AND OTHER BIOCHEMICAL}

\section{DATA}

Table 1 shows the results of serum lipids in three groups of patients. Phospholipid and total choles- terol levels were low in patients with cirrhosis of the liver and high in extrahepatic jaundice; the mean value of serum bile acids of patients with target cells was $156 \mu \mathrm{mol} / 1$, whereas in patients with cirrhosis a mean value of $45.6 \mu \mathrm{mol} / 1$ was found (Table 1 ). The pattern of serum bile acids differs in the two groups of patients: chenodeoxycholic acid was the predominant serum bile acid in cirrhosis, while cholic acid was higher in extrahepatic jaundice. The cholic:chenodeoxycholic acid ratio is low in cirrhosis $(0.7)$ and high in obstructive jaundice $(3 \cdot 1)$. Measurable lithocholic acid is present in patients with spur cell anaemia. The presence of spur cells in patients with liver cirrhosis was associated with higher values of serum bile acids, whereas the value of cholic-chenodeoxycholic acid ratio was lower. Other tests were even more altered when spur cells were present (Table4). The serumlipid lipoprotein composition (high density lipoproteins in particular) in the eight patients with spur cell anaemia showed very important changes: both the FC/PL and the free:esterified cholesterol ratios of HDL and LDL were higher than in control subjects (Tables 5 and 6). The percentage of fatty acids of HDL phospholipids and cholesterol esters is listed in Tables 7 and 8 ; in patients with spur cells a lower content of polyunsaturated fatty acids (linoleic, arachidonic, and docosaexaenoic acid) was found.

EFFECTS OF LECITHIN INFUSIONS

After polyunsaturated phosphatidylcholine infusion

Table 1 Clinical features of patients with cirrhosis of liver and extrahepatic jaundice compared with normal subjects

\begin{tabular}{|c|c|c|c|c|c|c|c|c|}
\hline \multirow[t]{3}{*}{ Groups (no.) } & \multicolumn{4}{|c|}{ Erythrocytes } & \multicolumn{4}{|l|}{ Serum* } \\
\hline & \multicolumn{2}{|c|}{ Osmotic resistance } & \multicolumn{2}{|c|}{ Morphology } & \multirow{2}{*}{$\begin{array}{l}T C \\
(m g / d l)\end{array}$} & \multirow{2}{*}{$\begin{array}{l}T G \\
(m g / d l)\end{array}$} & \multirow{2}{*}{$\begin{array}{l}P L \\
(m g / d l)\end{array}$} & \multirow{2}{*}{$\begin{array}{l}\text { Bile acids } \\
\text { ( } \mu \mathrm{mol} / \mathrm{l})\end{array}$} \\
\hline & Normal & Increased & Target & Spur & & & & \\
\hline Control (10) & 10 & 0 & 0 & 0 & $\begin{array}{r}198.6 \\
\pm 20.2\end{array}$ & $\begin{array}{r}87.6 \\
+21.4\end{array}$ & $\begin{array}{r}210.5 \\
\pm 28.6\end{array}$ & $\begin{array}{r}7.3 \\
\pm 1.8\end{array}$ \\
\hline $\begin{array}{l}\text { Cirrhosis (30) } \\
\text { Extrahepatic jaundice (10) }\end{array}$ & $\begin{array}{l}19 \\
(64 \%) \\
0\end{array}$ & $\begin{array}{l}11 \\
(36 \%) \\
10 \\
(100 \%)\end{array}$ & $\begin{array}{l}2 \\
(7 \%) \\
10 \\
(100 \%)\end{array}$ & $\begin{array}{l}12 \\
(40 \%) \\
0\end{array}$ & $\begin{array}{r}136.6 \\
\pm 18 \cdot 4 \\
406 \cdot 4 \\
\pm 49.6\end{array}$ & $\begin{array}{r}215 \cdot 4 \\
\pm 30 \cdot 4 \\
305 \cdot 0 \\
\pm 40 \cdot 2\end{array}$ & $\begin{array}{r}164 \cdot 4 \\
\pm 32 \cdot 6 \\
546 \cdot 7 \\
\pm 72 \cdot 6\end{array}$ & $\begin{array}{r}45 \cdot 6 \\
\pm 16 \cdot 2 \\
156 \cdot 2 \\
\pm 49 \cdot 8\end{array}$ \\
\hline
\end{tabular}

* Mean values and standard deviation.

TC: total cholesterol. TG: triglycerides. PL: phospholipids

Table 3 Fatty acid composition of phosphatidylcholine moiety of red blood cells (eight patients)

\begin{tabular}{|c|c|c|c|c|c|c|c|c|}
\hline Fatty acids & $16: 0$ & 18:0 & $18: 1$ & $18: 2$ & $20: 0+20: 1$ & $20: 3 \S$ & $20: 4$ & $22: 6$ \\
\hline $\begin{array}{l}\text { Controls } \\
\text { Spur cells } \\
\text { Spur cells after EPL }\end{array}$ & $\begin{array}{l}30 \cdot 2 \\
35 \cdot 4 \\
32 \cdot 2\end{array}$ & $\begin{array}{l}12 \cdot 1 \\
14 \cdot 1 \\
13 \cdot 1\end{array}$ & $\begin{array}{l}17 \cdot 2 \\
19 \cdot 5 \\
18 \cdot 2\end{array}$ & $\begin{array}{l}21 \cdot 6 \\
14 \cdot 2 * \\
18 \cdot 4 \ddagger\end{array}$ & $\begin{array}{l}1 \cdot 2 \\
2 \cdot 2 \\
2 \cdot 4\end{array}$ & $\begin{array}{l}1 \cdot 8 \\
1 \cdot 6 \\
1 \cdot 2\end{array}$ & $\begin{array}{l}7 \cdot 6 \\
4 \cdot 5 \dagger \\
6 \cdot 1\end{array}$ & $\begin{array}{l}3 \cdot 0 \\
1 \cdot 8 \\
2 \cdot 4\end{array}$ \\
\hline
\end{tabular}

${ }^{*} \mathbf{P}<0.01$ as compared to the controls.

tP $<0.05$ as compared to the controls.

$\ddagger P<0.05$ as compared to spur cells before EPL infusions.

$\S 20: 3 \omega 6$ 
Table 4 Clinical features of patients with cirrhosis, with or without spur cells (ranges and mean values)

\begin{tabular}{|c|c|c|c|c|c|c|c|c|}
\hline Group (no.) & $\begin{array}{l}\text { Total } \\
\text { bilirubin } \\
(m g / d l)\end{array}$ & $\begin{array}{l}\text { Unconjugated } \\
\text { bilirubin } \\
\text { (mg/dl) }\end{array}$ & $\begin{array}{l}\text { Albumin } \\
(g / d l)\end{array}$ & $\begin{array}{l}\text { Total } \\
\text { cholesterol } \\
(m g / d l)\end{array}$ & $\% C E$ & $\begin{array}{l}\text { Serum bile } \\
\text { acids } \\
(\mu \mathrm{mol} / \mathrm{l})\end{array}$ & $\begin{array}{l}C A \\
C D C A \\
\text { ratio }\end{array}$ & $\begin{array}{l}\text { Reticulocytes } \\
\left(\mathrm{mm}^{3}\right)\end{array}$ \\
\hline $\begin{array}{l}\text { With } \\
\text { spur cells (12) }\end{array}$ & $\begin{array}{l}5 \cdot 8-13 \cdot 6 \\
9 \cdot 2\end{array}$ & $\begin{array}{c}3 \cdot 0-9 \cdot 2 \\
6 \cdot 1\end{array}$ & $\begin{array}{c}1 \cdot 8-2 \cdot 4 \\
2 \cdot 1\end{array}$ & $\begin{array}{l}120 \cdot 195 \\
156\end{array}$ & $\begin{array}{c}38-51 \\
45\end{array}$ & $\begin{array}{l}19 \cdot 6-82 \cdot 5 \\
52 \cdot 5\end{array}$ & $\begin{array}{c}0.4-0.9 \\
0.52\end{array}$ & $\begin{array}{c}83,000-221,000 \\
143,000\end{array}$ \\
\hline $\begin{array}{l}\text { Without } \\
\text { spur cells (18) }\end{array}$ & $\begin{array}{l}4 \cdot 0-7 \cdot 4 \\
5 \cdot 5\end{array}$ & $\begin{array}{c}0.5-2.6 \\
1.7\end{array}$ & $\begin{array}{c}1 \cdot 8-2 \cdot 5 \\
2 \cdot 3\end{array}$ & $\begin{array}{c}164-212 \\
172\end{array}$ & $\begin{array}{c}46-60 \\
53\end{array}$ & $\begin{array}{l}13 \cdot 8-64 \cdot 5 \\
38 \cdot 4\end{array}$ & $\begin{array}{c}0.7-1 \cdot 2 \\
0.89\end{array}$ & $\begin{array}{c}26,000-108,000 \\
48,000\end{array}$ \\
\hline
\end{tabular}

CE: cholesterol esters.

CA : cholic acid.

CDCA: chenodeoxycholic acid.

Table 5 Chemical composition of high density lipoprotein in normal subjects and in patients with spur cell anaemia before and after EPL infusion

\begin{tabular}{|c|c|c|c|c|}
\hline \multirow[t]{2}{*}{ Component } & \multicolumn{2}{|c|}{ Normal (8) } & \multicolumn{2}{|c|}{ Spur cells (8) } \\
\hline & $\begin{array}{l}\text { Before } \\
\text { (mmol/l) }\end{array}$ & $\begin{array}{l}\text { After } \\
\text { (mmol/l) }\end{array}$ & $\begin{array}{l}\text { Before } \\
\text { (mmol/l) }\end{array}$ & $\begin{array}{l}\text { After } \\
(\mathrm{mmol} / \mathrm{l})\end{array}$ \\
\hline $\begin{array}{l}\text { Protein } \\
\text { Cholesterol ester } \\
\text { Free cholesterol } \\
\text { Phospholipids } \\
\text { Triglycerides }\end{array}$ & $\begin{array}{l}0.026 \\
1.098 \\
0 \cdot 167 \\
1.048 \\
0.098\end{array}$ & $\begin{array}{l}0.024 \\
0.931 \\
0.122 \\
1.015 \\
0.069\end{array}$ & $\begin{array}{l}0.012 \\
0.728 \\
0.269 \\
0.773 \\
0.087\end{array}$ & $\begin{array}{l}0 \cdot 011 \\
0 \cdot 663 \\
0 \cdot 182 \\
0 \cdot 772 \\
0 \cdot 047\end{array}$ \\
\hline$\overline{\mathrm{CE}}$ ratio & $0 \cdot 15$ & $0 \cdot 13$ & $0 \cdot 37$ & $0 \cdot 27^{*}$ \\
\hline$\frac{\mathrm{FC}}{\mathrm{PL}}$ ratio & $0 \cdot 15$ & $0.11^{*}$ & 0.33 & $0.23 \dagger$ \\
\hline
\end{tabular}

$*_{P}<0.05$

$\dagger \mathrm{P}<0.01$

Table 6 Chemical composition of low density lipoprotein in normal subjects and in patients with spur cell anaemia before and after EPL infusion

\begin{tabular}{|c|c|c|c|c|}
\hline \multirow[t]{2}{*}{ Component } & \multicolumn{2}{|c|}{ Normal (8) } & \multicolumn{2}{|c|}{ Spur cells $(8)$} \\
\hline & $\begin{array}{l}\text { Before } \\
\text { (mmol/l) }\end{array}$ & $\begin{array}{l}\text { After } \\
\text { (mmol/l) }\end{array}$ & $\begin{array}{l}\text { Before } \\
(\mathrm{mmol} / \mathrm{l})\end{array}$ & $\begin{array}{l}\text { After } \\
(\text { mmol } / \mathrm{l})\end{array}$ \\
\hline $\begin{array}{l}\text { Protein } \\
\text { Cholesterol ester } \\
\text { Free cholesterol } \\
\text { Phospholipids } \\
\text { Triglycerides }\end{array}$ & $\begin{array}{l}0.012 \\
3.658 \\
0.965 \\
1.153 \\
0.351\end{array}$ & $\begin{array}{l}0.012 \\
3 \cdot 812 \\
0.997 \\
1 \cdot 267 \\
0 \cdot 330\end{array}$ & $\begin{array}{l}0 \cdot 007 \\
2 \cdot 141 \\
1 \cdot 202 \\
0 \cdot 858 \\
0 \cdot 561\end{array}$ & $\begin{array}{l}0.006 \\
2 \cdot 527 \\
1 \cdot 181 \\
0.989 \\
0.487\end{array}$ \\
\hline$\frac{\mathrm{FC}}{\overline{\mathrm{CE}}}$ ratio & 0.27 & 0.27 & $0 \cdot 56$ & 0.48 \\
\hline$\frac{\text { FC }}{\overline{P L}}$ ratio & 0.82 & 0.79 & $1 \cdot 40$ & $1 \cdot 21$ \\
\hline
\end{tabular}

in eight patients with spur cell anaemia there was a reduction of the percentage of spur cells (from 59 to $24 \%$ of total erythrocytes); the osmotic fragility decreased in only two cases. The C/PL molar ratio of red blood cells fell significantly from 1.22 to 0.88 $(\mathrm{P}<0.01)$.

Both unconjugated bilirubin and reticulocytes decreased in patients treated, whereas LCAT activity (from 31.2 to $54.4 \mu \mathrm{mol} / \mathrm{l} / \mathrm{h}$ ) and the linoleic acid content of red blood cells phosphati- dylcholine increased $(P<0.05)$ (Tables 3 and 9). Even the lipoprotein composition was changed after EPL infusion; HDL showed the most important variations: the $\mathrm{FC} / \mathrm{PL}$ molar ratio decreased from 0.33 to $0.23(P<0.01)$ and the free:esterified cholesterol ratio decreased from 0.37 to 0.27 $(P<0.05)$ (Table 5). Changes in LDL composition were not statistically significant (Table 6). Fatty acid composition of phospholipids and cholesterol esters showed an increase in the percentage of linoleic acid both in controls and in patients with spur cell anaemia $(P<0.01)$ (Tables 7 and 8$)$.

Table 7 Fatty acid composition of HDL-phospholipids in controls and in patients with spur cell anaemia before and after EPL infusion*

\begin{tabular}{|c|c|c|c|c|}
\hline \multirow[t]{2}{*}{ Fatty acid } & \multicolumn{2}{|c|}{ (N) Normal (8) } & \multicolumn{2}{|c|}{ (SC) Spur cell anaemia (8) } \\
\hline & Before & After & Before & After \\
\hline $16: 0$ & $26 \cdot 9$ & $22 \cdot 7$ & 33.6 & $23 \cdot 1$ \\
\hline $16: 1$ & $3 \cdot 8$ & $2 \cdot 6$ & 3.9 & $4 \cdot 6$ \\
\hline $18: 0$ & $17 \cdot 3$ & $15 \cdot 2$ & $16 \cdot 9$ & $15 \cdot 4$ \\
\hline $18: 1$ & $16 \cdot 8$ & $14 \cdot 8$ & $24 \cdot 4$ & $19 \cdot 7 \ddagger$ \\
\hline $18: 2$ & $20 \cdot 8$ & $29 \cdot 6 \ddagger$ & $14 \cdot 6+$ & $28 \cdot 6 \S$ \\
\hline $20: 4$ & $9 \cdot 7$ & 10.6 & $2 \cdot 7 \dagger$ & $4.6 \S$ \\
\hline $22: 6$ & $2 \cdot 9$ & $3 \cdot 1$ & $1.6 \dagger$ & $2 \cdot 0$ \\
\hline
\end{tabular}

*The values are given as molar percentages.

$t_{P}<0.05$ between $\mathrm{SC}$ and $\mathrm{N}$ in the basal condition.

$\pm P<0.05$ between before and after infusion.

$\S P<0.01$ between before and after infusion.

Table 8 Fatty acid composition of HDL-cholesterol ester in controls and in patients with spur cell anaemia before and after EPL infusion*

\begin{tabular}{|c|c|c|c|c|}
\hline \multirow[t]{2}{*}{ Fatty acid } & \multicolumn{2}{|c|}{ (N) Normal (8) } & \multicolumn{2}{|c|}{ (SC) Spur cell anaemia (8) } \\
\hline & Before & After & Before & After \\
\hline $\begin{array}{l}16: 0 \\
16: 1 \\
18: 0 \\
18: 1 \\
18: 2 \\
20: 4\end{array}$ & $\begin{array}{r}14 \cdot 4 \\
5 \cdot 2 \\
2 \cdot 3 \\
20 \cdot 6 \\
48 \cdot 2 \\
5 \cdot 1\end{array}$ & $\begin{array}{r}12 \cdot 1 \\
4.3 \\
1.8 \\
19.6 \\
51.4 \\
6.4\end{array}$ & $\begin{array}{r}18.8 \\
9.4 \\
1.6 \\
29.7 \dagger \\
36.3 \dagger \\
2.0 \dagger\end{array}$ & $\begin{array}{c}16 \cdot 2 \\
7 \cdot 4 \\
2 \cdot 1 \\
25 \cdot 4 \ddagger \\
40 \cdot 7 \\
3 \cdot 6 \ddagger\end{array}$ \\
\hline
\end{tabular}

*The values are given as molar percentages.

$t_{P}<0.01$ between $S C$ and $N$ in the basal condition.

$\ddagger P<0.05$ between before and after EPL infusion. 
Table 9 Effects of EPL infusion in eight patients with spur cell anaemia (ranges and mean values)

\begin{tabular}{|c|c|c|}
\hline & \multicolumn{2}{|l|}{ EPL infusion } \\
\hline & Before & After \\
\hline $\begin{array}{l}\text { Reticulocytes } \\
\left(\mathrm{mm}^{3}\right)\end{array}$ & $93000-210000$ & $54000-165000$ \\
\hline $\begin{array}{l}\text { Unconjugated bilirubin } \\
(\mathrm{mg} / \mathrm{dl})\end{array}$ & $\begin{array}{c}3 \cdot 0-9 \cdot 2 \\
6 \cdot 1\end{array}$ & $\begin{array}{c}2 \cdot 4 \cdot 6 \cdot 8 \\
4 \cdot 8\end{array}$ \\
\hline C & $1 \cdot 01-1 \cdot 58$ & $0 \cdot 78-0.95$ \\
\hline$\overline{\mathbf{P L}}$ molar ratio in red cells & $1 \cdot 22$ & $0.88+$ \\
\hline $\begin{array}{l}\text { Red cell morphology } \\
\% \text { spur cells }\end{array}$ & $\begin{array}{c}45-80 \\
59 \cdot 5\end{array}$ & $\begin{array}{c}20-30 \\
23 \cdot 8\end{array}$ \\
\hline $\begin{array}{l}\text { LCAT activity } \\
\left(\mu \mathrm{mol} / \mathrm{I}^{-1} / \mathrm{h}^{-1}\right)\end{array}$ & $\begin{array}{l}20 \cdot 4-43 \cdot 0 \\
31 \cdot 2\end{array}$ & $\begin{array}{l}31 \cdot 9-89 \cdot 9 \\
54 \cdot 4^{*}\end{array}$ \\
\hline $\begin{array}{l}\text { Serum bile acids } \\
(\mu \mathrm{mol} / \mathrm{l})\end{array}$ & $\begin{array}{c}29 \cdot 9-69 \cdot 6 \\
51 \cdot 4\end{array}$ & $\begin{array}{c}30 \cdot 5-75 \cdot 4 \\
57 \cdot 7\end{array}$ \\
\hline$\%$ deoxycholic acid & 12 & 43 \\
\hline
\end{tabular}

Discussion

RED CELL MORPHOLOGY AND MEMBRANE LIPIDS: INFLUENCE OF PLASMA LIPOPROTEINS

Lipid interactions in the erythrocyte membranes with subsequent changes of membrane fluidity may determine the morphology of red blood cells (Cooper 1977). The C/PL molar ratio seems to distinguish spur cells from target cells as shown by Cooper et al. (1972): target cells are rich in both cholesterol and phospholipids, whereas spur cell membranes contain more cholesterol with respect to phospholipids. The increase of cholesterol has a condensing effect and reduces acyl chain mobility (Papahadjopoulos, 1974) with the decrease of polyunsaturated fatty acid content within the phospholipid acyl chains. Both these changes make the membranes of the red blood cells more rigid and less fluid. It is unlikely that cholesterol loading is the only mechanism underlying spur cell genesis and determining thorny-shaped red blood cells in patients with severe liver disease (McBride and Jacob, 1970). In fact, the membrane cholesterol of red blood cells in patients with hereditary absence of plasma LCAT is $60-90 \%$ greater than normal, probably because of the marked increase in plasma free cholesterol in this condition (Nørum and Gjone, 1968), but target cells rather than spur cells have been reported in these patients. Moreover, the acanthocytes (spur cell-like) of abetalipoproteinaemia have a normal value of C/PL molar ratio but a low amount of polyunsaturated fatty acids (Dodge et al., 1967). Our results showed a selective increase of cholesterol content in spur cells and a reduction of polyunsaturated fatty acids of lecithin. These two factors may contribute to form membrane in which fluidity is low: the redundant membranes induce red blood cells to wrinkle producing spur cells. Which mechanism is responsible for lipid changes in red blood cell membranes? In man, about $60 \%$ of erythrocyte phosphatidylcholine is exchangeable with lipoproteins, but free cholesterol exchanges more extensively (Reed et al., 1968). The cholesterol exchange between plasma lipoprotein and red blood cells depends on the FC/PL molar ratio of lipoproteins (Cooper et al., 1972). Red cells acquire cholesterol if lipoprotein FC/PL molar ratio increases (Cooper, 1977), as observed in HDL of our patients with spur cell anaemia. The exchange is less between red blood cells and LDL and more considerable with HDL (Quarfordt and Hilderman, 1970). Even LCAT activity regulating the plasma free cholesterol levels may influence the cholesterol concentration in erythrocytes (Glomset, 1968). Simon (1971) described a selective increase in red blood cell cholesterol in patients with liver disease whose LCAT activity is frequently low, as found in our patients with spur cell anaemia. A low content of polyunsaturated fatty acids has been found in the plasma by Jaeger et al. (1975) and also in red blood cell lipid by Schubotz et al. (1976) during ethanol induced hyperlipidaemia and by Neerhout (1968) in patients with liver disease.

SPUR CELLS AND BILE SALTS

An increase of SBA may be important for haemolysis (Palmer, 1964) and for spur cell formation. It is known that in lithocholic acid-fed monkeys spurring precedes the increase of cholesterol red blood cell membrane (Cooper et al., 1972). Cooper and Jandl (1968) concluded that increased SBA causes cholesterol accumulation in red blood cell membrane because of the inhibiting effect of bile salts on cholesterol esterification; but bile acids may influence LCAT activity only at a concentration of 4-6 $\mathrm{mmol} / \mathrm{l}:$ in these concentrations bile salts disrupt HDL (Ho and Nichols, 1971), the preferred substrate for LCAT activity (Salvioli et al., 1977). Serum bile acids are high in patients with spur cells compared with subjects with liver cirrhosis without spur cells and the cholic:chenodeoxycholic acid ratio is high in patients with extrahepatic jaundice and low in patients with severe liver cirrhosis. After EPL infusion, serum bile acids increase along with a greater percentage of deoxycholic acid; this bile acid is detergent on fibroblast but for concentrations of $1.25-1.6 \mathrm{mmol} / \mathrm{l}$ only (Trias et al., 1977). Therefore, the changes of serum bile acids do not seem responsible for both haemolysis and the spurring process, as the percentage of spur cells decreases even if the concentration of serum bile 
acids becomes higher after phosphatidylcholine infusion.

\section{EFFECTS OF LECITHIN INFUSION ON LIPID COMPOSITION AND MORPHOLOGY OF SPUR CELLS}

Exchange between infused and endogenous lecithin is known; Thompson et al. (1976) reported that HDL lecithin showed the most marked increase in oleic acid after oleic-rich lecithin infusion. In our patients EPL infusion increased the content of linoleic acid in HDL phospholipids which before infusion had low polyunsaturated fatty acid levels; after infusion even the FC/PL molar ratio in HDL decreased.

We mentioned before the lipid exchange between RC and lipoprotein: recently Verkleij et al. (1976) demonstrated fusion of cholestatic lipoprotein (LP-X) and uptake of its cholesterol and lecithin with RC membranes. Polyunsaturated phosphatidylcholine introduced into the blood may also be incorporated as intact molecules into the circulating membranes (Wagener, 1972). EPL infusion reduces both cholesterol content and C/PL ratio of spur cells, while their linoleic acid content of lecithin increases.

The cholesterol depletion with concomitant reduction of spur cell percentage may depend on the following factors:

\section{Detergent effect of lecithin}

Red cells in rodents are depleted of cholesterol in vivo after infusion of high doses $(4 \mathrm{~g} / \mathrm{kg} /$ day) of egg lecithin (Robins and Miller, 1974); but during egg lecithin infusion in man there is an increase of both FC and LDL levels (Thompson et al., 1976), probably because of the greater ratio between oleic and linoleic acid observed after the infusion (Peeters et al., 1973; Thompson et al., 1975). In our patients both the oleic: linoleic acid ratio and the ratio between free and esterified cholesterol decreased after EPL infusion; on the other hand, LDL levels tended to fall.

Higher content of linoleic acid in spur cell membranes The higher content of linoleic acid in spur cell membranes increases membrane fluidity and prevents the effects of an excess of cholesterol in the red cell membranes (Papahadjopoulos, 1974).

Higher content of linoleic acid in $H D L$ phospholipids and lower FC/PL molar ratio of $H D L$, after EPL infusion

In fact, the activation of LCAT is most effective with lecithin containing an unsaturated fatty acid chain (Soutar et al., 1975).
The increase of LCAT activity increases the cholesterol ester formation and consequently decreases the FC/PL ratio, on which the transfer of cholesterol from plasma lipoproteins to cell membranes depends (Cooper, 1977). High density lipoproteins have been shown to be particularly effective in removing red blood cell cholesterol; when the more reactive HDL subfractions obtained by gel filtration are incubated in the presence of LCAT and erythrocytes, the total HDL cholesterol can increase by $100 \%$ or more (Glomset, 1972).

For these reasons, low doses of infused lecithin may change both the composition and the shape of spur cells, thus ameliorating haemolytic anaemia.

\section{References}

Bartlett, G. R. (1959). Phosphorus assay in column chromatography. Journal of Biological Chemistry, 234, 466-468.

Bruckdorfer, K. R., Demel, R. A., De Gier, J., and Van Deenen, L. L. M. (1969). The effect of partial replacements of membrane cholesterol by other steroids on the osmotic fragility and glycerol permeability of erythrocytes. Biochimica et Biophysica Acta, 183, 334-345.

Cooper, R. A. (1977). Abnormalities of cell-membrane fluidity in the pathogenesis of disease. New England Journal of Medicine, 297, 371-377.

Cooper, R. A., Arner, E. C., Wiley, J. S., and Shattil, S. J. (1975). Modification of red cell membrane structure by cholesterol-rich lipid dispersions. A model for the primary spur cell defect. Journal of Clinical Investigation, 55, 115-126.

Cooper, R. A., Diloy-Puray, M., Lando, P., and Greenberg, M. S. (1972). An analysis of lipoproteins, bile acids, and red cell membranes associated with target cells and spur cells in patients with liver disease. Journal of Clinical Investigation, 51, 3182-3192.

Cooper, R. A., Garcia, F. A., and Trey, C. (1972). The effect of lithocholic acid on red cell membranes in vivo. Journal of Laboratory and Clinical Medicine, 79, 7-18.

Cooper, R. A., and Jandl, J. H. (1968). Bile salts and cholesterol in the pathogenesis of target cells in obstructive jaundice. Journal of Clinical Investigation, 47, 809-822.

Cooper, R. A., Kimball, D. B., and Durocher, J. R. (1974). Role of the spleen in membrane conditioning and hemolysis of spur cells in liver disease. New England Journal of Medicine, 290, 1279-1284.

Dodge, J. T., Cohen, G., Kayden, H. J., and Phillips, G. P. (1967). Peroxidative hemolysis of red blood cells from patients with abetalipoproteinemia (acanthocytosis). Journal of Clinical Investigation, 46, 357-368.

Glomset, J. A. (1968). The plasma lecithins: cholesterol acyltransferase reaction. Journal of Lipid Research, 9, 155-167.

Glomset, J. A. (1972). Plasma lecithin:cholesterol acyltransferase. In Blood Lipids and Lipoproteins: Quantitation, Composition, and Metabolism, p. 773. Edited by G. J. Nelson. Wiley-Interscience: New York.

Hatch, F. T. (1968). Practical methods for plasma lipoprotein analysis. Advances in Lipid Research, '(see pp. 33-36)', 6, 1-68.

Ho, W. K. K., and Nichols, A. V. (1971). Interaction of lecithin: cholesterol acyltransferase with sonicated dispersions of lecithin. Biochimica et Biophysica Acta, 231, 185-193.

Kimelberg, H. K., and Papahadjopoulos, D. (1974). Effects 
of phospholipid acyl chain fluidity, phase transitions, and cholesterol on $\left(\mathrm{Na}^{+}-\mathrm{K}^{+}\right)$-stimulated adenosine triphosphatase. Journal of Biological Chemistry, 294, 1071-1080.

Jaeger, H. Kloer, H. U., and Rakow, A. D. (1975). Studies on the essential fatty acid deficiency in liver disease. Abstracts of the Ninth Annual Meeting of the European Society for Clinical Investigation, Rotterdam, April 24-26, p. 70.

Lowry, O. H., Rosebrough, N. J., Farr, A. L., and Randall, R. J. (1951). Protein measurement with the Folin phenol reagent. Journal of Biological Chemistry, 193, 265-275.

McBride, J. A., and Jacob, H. S. (1970). Abnormal kinetics of red cell membrane cholesterol in acanthocytes: studies in genetic and experimental abetalipoproteinaemia and in spur cell anaemia. British Journal of Haematology, 18, 383-397.

Morrison, W. R., and Smith, L. M. (1964). Preparation of fatty acid metyl esters and dimetylacetals from lipids with boron fluoride methanol. Journal of Lipid Research, 5, 600-608.

Neerhout, R. C. (1968). Abnormalities of erythrocyte stromal lipids in hepatic disease. Journal of Laboratory and Clinical Medicine, 71, 438-447.

Nørum, K. R., and Gjone, E. (1968). The influence of plasma from patients with familial plasma lecithin: cholesterol acyltransferase deficiency on the lipid pattern of erythrocytes. Scandinavian Journal of Clinical and Laboratory Investigation, 22, 94-98.

Palmer, R. H. (1964). Haemolytic effects of steroids. Nature, 201, 1134-1135.

Papahadjopoulos, D. (1974). Cholesterol and cell membrane function: a hypothesis concerning the ethiology of atherosclerosis. Journal of Theoretical Biology, 43, 329-337.

Parpart, A. K., Lorenz, P. B., Parpart, E. R., Gregg, J. R., and Chase, A. M. (1947). The osmotic resistance (fragility) of human red cells. Journal of Clinical Investigation, 26, 636-640.

Peeters, H., Blaton, V., Soeteway, F., Declercq, B., and Vandamme, D. (1973). Wirkung der "essentiellen" Phospholipide auf Plasmalipide und Fettsäuren beim Typ II der Hyperlipoproteinämie. Münchener Medizinische Wochenschrift, 115, 1358-1362.

Quarfordt, S. H., and Hilderman, H. L. (1970). Quantitation of the in vitro free cholesterol exchange of human red cells and lipoproteins. Journal of Lipid Research, 11, 528-535.

Reed, C. F., Murphy, M., and Roberts, G. (1968). Phospholipid exchange between plasma and erythrocytes in man and the dog. Journal of Clinical Investigation, 47, 749-760.

Robins, S. J., and Miller, A. (1974). Red cell cholesterol depletion and the formation of spiculated cells in vivo. Journal of Laboratory and Clinical Medicine, 83, 436-443.
Salvioli, G., Lugli, R., and Salati, R. (1977). Lipid substrates for LCAT activity in liver disease. Scandinavian Journal of Gastroenterology, 12, 841-847.

Salvioli, G., Salati, R., Lugli, R., and Baldelli, M. V. (1974). La determinazione quantitativa e qualitativa degli acidi biliari nel siero. Il Fegato, 20, 77-88.

Schubotz, R., Goebel, K. M., and Kaffarnik, H. (1976). Veränderungen in den Membranlipiden der Erythrocyten bei äthanolinduzierter Hyperlipidämie (Zieve-Syndrom). Klinische Wochenschrift, 54, 827-833.

Shohet, S. B. (1972). Hemolysis and changes in erythrocyte membrane lipids. Part I. New England Journal of Medicine, 286, 577-583.

Simon, J. B. (1971). Red cell lipids in liver disease: relationship to serum lipids and to lecithin-cholesterol acyltransferase. Journal of Laboratory and Clinical Medicine, 77, 891-900.

Smith, J. A., Lonergan, E. T., and Sterling, K. (1964). Spur cell anemia: hemolytic anemia with red cells resembling acanthocytes in alcoholic cirrhosis. New England Journal of Medicine, 271, 396-398.

Soutar A. K., Garner, C. W., Baker, H. N., Sparrow, J. T., Jackson, R. L., Gotto, A. M., and Smith, L. C. (1975). Effect of the human plasma apolipoproteins and phosphatidylcholine acyl donor on the activity of lecithin: cholesterol acyltransferase. Biochemistry, 14, 3057-3064.

Stokke, K. T., and Norum, K. R. (1971). Determination of lecithin: cholesterol acyltransfer in human blood plasma. Scandinavian Journal of Clinical and Laboratory Investigation, 27, 21-27.

Thompson, G. R., Jadhav, A., Nava, M., and Gotto, A. M. Jr. (1976). Effects of intravenous phospholipid on low density lipoprotein turnover in man. European Journal of Clinical Investigation, 6, 241-248.

Thompson, G. R., Segura, R., Hoff, H., Gotto, A. M. Jr. (1975). Contrasting effects of plasma lipoproteins of intravenous versus oral administration of a triglyceridephospholipid emulsion. European Journal of Clinical Investigation, 5, 373-384.

Trias, X., Strebel, H. M., Paumgartner, G., and Wiesmann, U. N. (1977). Effects of bile and bile acids on culturated human fibroblasts. European Journal of Clinical Investigation, 7, 189-194.

Verkleij, A. J., Nauta, l. L. D., Werre, J. M., Mandersloot, J. G., Reinders, B., Ververgaert, P. H. J. T., and De Gier, J. (1976). The fusion of abnormal plasma lipoprotein (LP-X) and the erythrocyte membrane in patients with cholestasis studied by electron microscopy. Biochimica et Biophysica Acta, 436, 366-376.

Wagener, H. (1972). Preparation, distribution and turnover of tritium-labelled 'essential' phospholipids (EPL). In Phospholipide in Biochemie, Experiment und Klinik, pp. 59-69. Edited by G. Schettler. Thieme: Stuttgart. 